\title{
Editor's Exordium
}

\section{Diversified experimentation in horticulture}

\author{
"I haven't failed. I've just found 10,000 ways that won't work" \\ (The Fabulous Drone, 1967, Thomas Edison)
}

This issue yet again marks a compendium of articles on diverse crops and aspects in horticulture. This multifariousness or the absence of monotony is indeed a mark of dynamism in science experimentation, especially and specially in the field of horticulture.

In vegetables, Varalakshmi et al have investigated into the determination of the variability, heritability, genetic advance and correlation of fruit yield and yield contributing characters in bottle gourd (Lagenaria siceraria (Mol. Stadl.)), emphasizing the importance of indirect selection. Gupta et al have utilized a bioinformatics approach to identify microRNAs from partial genome sequence data in okra by next generation sequencing (NGS) technology and identified two miRNAs and their cognate target RNAs. Kurian et al, in their study, have explored the predisposing factors leading to the occurrence of inflorescence blight and pod rot in Dolichos bean (Dolichos lablab $L$.) and yard long bean, and the pathogen identified as Choanephora infundibulifera. Anitha et al studied the effects of weed management practices on seed yield and quality of bitter gourd (Momordica charantia), in terms of weed control efficiency, mulching effects, germination and vigour indices. Higher seedling lengths and fresh weights were sweetly recorded, of course. NasiyaBeegum and Subramanian evaluated cowpea accessions for resistance to the spotted pod borer, Maruca vitrata (Fab.; Lepidoptera: Crambidae) by examining calyx configurations and sepals while indicating that tight calyx could possibly deter entry of freshly hatched first instar larval instars. Surya et al investigated the quality performance of coriander leaves under open and rain shelter conditions in terms of herbage, biomass yield, vitamin $C$ content, volatile oil content and total chlorophyll contents. Anyways, the smooth lingering aroma of fresh coriander leaves in Indian kitchen needs no emphasis.

In fruits, Shikhamany et al conducted a nutritional survey to study the quadratic relationship and influence of variety and rootstock on various cation interactions in grapes. The soil $\mathrm{Na}^{+}, \mathrm{K}^{+}$ and $\mathrm{Ca}^{++}$had varied absorption and interaction dynamics in different grapes rootstock and scions. Covering the post harvest aspects in fruit crops, Muralidhara et al assessed the post harvest changes in bioactive phytonutrients and total antioxidant activity during ripening of mango $c v$. Amrapali, through the analysis of total antioxidants, total phenols, total flavonoids and total carotenoids while noticing the profound effects of ripening on the post harvest composition of nutraceuticals. Ranjitha et al screened strains of Lactobacillus helveticus, L. rhamnosus and Saccheromyces boulardii towards the development of ready-to-serve probioticated mango beverages. 
Interestingly, hic!, L. helveticus probioticated mango beverage showed improved acceptability and higher nutrients. Pushpa Chethan Kumar et al prepared Moringa, a tree-vegetable hybrid, infusions along with some herbs/flavouring agents such as tulsi, ginger and lemon grass for green tea and evaluated the organoleptic properties. This desi/traditional/heirloom crop and concoction combination, potent I must say, offers a new coffee table book recipe!

Menon and Shibana evaluated the performance of two garlic (Allium sativum L.) genotypes in the plains of Kerala in terms of bulb weight and number of cloves per bulb, the two main yield components and suggesting the possibilities of garlic cultivation in the new niche with some refinements in the agrotechniques.

Dhanasekaran studied the effects of different sprigging densities and foliar nitrogen on the growth and establishment of Bermuda grass (Cynodon dactylon L. Pers. X Cynodon transvaalensis), with not surprisingly, the usual urea at $2 \%$ proved better.

In floriculture, Sathappan studied the performance of genotypes of tuberose (Polyanthes tuberosa L.) and identified genotypes with high heritability and in terms of various yield traits, suitable for the coastal region and future breeding programs. Praveen et al, through a purposive sampling survey, revealed the existence of powdery mildew in gerbera crop grown under protected and open conditions, on the scenic hilly tracts of Wayanad, Kerala. Characterization of pathogens, Golovinomyces cichoracearum and Podosphaera sp., indicated differential disease incidence and severity. Dhanasekaran also examined the influence of growth regulators on jasmine (Jasminum sambac Ait.) in terms of flowering attributes and inferred that the good old gibberellic acid can enhance growth and flower yield.

IN THIS ISSUE, papers on fruits (3), vegetables (6), spices (2) and flower (3) crops and one weed, have dwelled on genetic (2), post harvest (2), pest (1), disease (2), quality (1), agronomic (6) and biochemical (1) studies, thus again reassuring you, the readers, that indeed THIS ISSUE, also is as diversified in its content, as its previous brethren.

On behalf of the Executive Council and the Editorial Board, I humbly thank and acknowledge all the referees et al for critically reviewing the submitted manuscripts, for both the issues. I also request the readers and potential contributors to mainly consider online manuscript submission route. This is the only unfailing way, to respect Edison as in the opening quotable quote!

Vageeshbabu S. Hanur Editor in Chief Journal of Horticultural Sciences 